\title{
KEDUDUKAN BADAN PERMUSYAWARATAN \\ DESA DALAM PEMERINTAHAN DESA \\ (Studi di Desa Deket Wetan Kecamatan Deket Kabupaten Lamongan )
}

\author{
Oleh \\ Munif Rochmawanto \\ Dosen Fakultas Hukum Universitas Islam Lamongan
}

\begin{abstract}
ABSTRAK
Badan Permusyawaratan Desa belum berpengalaman dalam memahami dan merumuskan agenda-agenda yang diharapkan secara efektif untuk menciptakan pembaruan di desa. Anggota Badan Permusyawaratan Desa di Desa Deket cukup banyak yang belum memahami hak dan tanggungjawabnya sebagai kekuatan legislasi dan pengontrol. Hal inilah yang menjadi alasan masyarakat Desa Deket menyalurkan aspirasinya hanya melalui Kepala Desa. Wajar bila kemudian, dalam penyelenggaraan Pemerintahan Desa, Kepala Desa masih lebih dominan dari pada Badan Permusyawaratan Desa. Dari uraian yang dikemukakan dalam latar belakang masalah di atas, maka dapat dirumuskan beberapa permasalahan sebagai berikut : 1) Bagaimanakah Kedudukan Badan Permusyawaratan Desa dalam Pemerintahan Desa ? 2) Bagaimana Tata Cara Pengangkatan Badan Permusyawaratan Desa ? sedangkan Tipe penelitian hukum yang di lakukan adalah yurdis nomatif (hukum normatif). Metode penelitian nomaatif adalah suatu prosedur penelitian ilmiah untuk menemukan kebenaran berdasarkan logika keilmuan hukum dari sisi normative.Kedukan Badan Permusyawaratan Desa dalam pemerintahan desaadalah sebagai jembatan antara elemen masyarakat dan Pemerintah Desa, dan merupakan wahana untuk melaksanakan demokrasi pancasilan dan kedudukannya dalam pemerintahan desa adalah sejajar dan menjadi mitra dari Pemerintah Desa.
\end{abstract}

Kata Kunci : BPD, Pemerintahan Desa.

\section{A. PENDAHULUAN.}

Demokrasi dipahami sebagai sebuah ruang lingkup yang sangat luas. Apapun bentuknya, fenomena demokrasi sangat menarik untuk dibicarakan. Apalagi jika dikaitkan dengan kenyataan, bahwa negara Indonesia merupakan negara yang masih menjadikan proses demokratisasi sebagai sebuah tumpuan. Konsep Negara demokrasi dalam kepustakaan dikenal sebagai suatu bentuk atau mekanisme bagaimana sistem pemerintahan dalam suatu Negara dijalankan oleh pemerintah Negara tersebut.

Perlu diketahui bahwa keberadaan kelembagaan kelompok tani di Desa Deket sangat penting diberdayakan karena potensinya sangat besar. Kelembagaan kelompok tani ini sangat efektif sebagai sarana untuk kegiatan belajar, bekerja sama, dan pemupukan modal kelompok dalam mengembangkan usaha tani di kabupaten Lamongan khususnya di Desa Deket Wetan. Selain itu, tujuan dari kegiatan kelompok tersebut adalah untuk meningkatkan produksi dan produktivitas usaha tani, serta tingkat kesejahteraan petani.

Namun, kenyataannya anggota Badan Permusyawaratan Desa belum berpengalaman dalam memahami dan merumuskan agenda-agenda yang diharapkan secara efektif untuk menciptakan pembaruan di desa. Anggota Badan Permusyawaratan Desa 
di Desa Deket Wetan cukup banyak yang belum memahami hak dan tanggungjawabnya sebagai kekuatan legislasi dan pengontrol. Hal inilah yang menjadi alasan masyarakat Desa Deket Wetan menyalurkan aspirasinya hanya melalui Kepala Desa. Wajar bila kemudian, dalam penyelenggaraan Pemerintahan Desa, Kepala Desa masih lebih dominan dari pada Badan Permusyawaratan Desa. Padahal fungsi dari kepala desa menurut Undang-Undang No. 6 tahun 2014 tentang Desa Pasal 26 adalah menyelenggarakan pemerintahan desa, melaksanakan pembangunan desa, pembinaan kemasyarakatan desa. Dalam menyelenggarakan hal tersebut, kepada desa harus menjalin kerja sama dan koordinasi dengan seluruh pemangku kepentingan di Desa termasuk dengan Badan Permusyawaratan Desa. Adapun, bentuk kerja sama yang dijalin dengan badan permusyawaratan desa tersebut adalah mengenai tindak lanjut dari aspirasi masyarakat desa agar dapat terlaksana. Artinya, dalam hal ini aspirasi tersebut haruslah berjenjang tidaklah aspirasi tersebut diterima dan dihimpun oleh kepala desa saja namun haruslah memanfaatkan Badan Permusyawaratan Desa setempat. Hal tersebut, dimulai dari Badan Permusyawaratan Desa sebagai perangkat desa yang menghimpun aspirasi, kemudian ditindaklanjuti dengan melakukan kerja sama bersama Kepala Desa sebagai penyelenggara pemerintah desa yang berwenang untuk mengambil keputusan.

Dari uraian yang dikemukakan dalam latar belakang masalah di atas, maka dapat dirumuskan beberapa permasalahan sebagai berikut :

1. Bagaimanakah Kedudukan Badan Permusyawaratan Desa dalam Pemerintahan Desa?
2. Bagaimana Tata Cara

Pengangkatan Badan

Permusyawaratan Desa?

\section{B. METODE PENELITIAN}

Tipe penelitian hukum yang di lakukan adalah yurdis nomatif (hukum normatif). Metode penelitian nomaatif adalah suatu prosedur penelitian ilmiah untuk menemukan kebenaran berdasarkan logika keilmuan hukum dari sisi normatif.

Oleh karena itu penelitian hukum ini di fokuskan untuk mengkaji penelitian hokum tentang kaidahkaidah atau norma-norma dalam hukum positif, yakni norma hokum yang terkait dengan kedudukan Badan Permusyawaratan Desa dalam Pemerintahan Desa

Oleh karena tipe penelitian yang digunakan adalah tipe penelitian yuridis normatif, maka pendekatan yang digunakan adalahpendekatan perundang-undangan (statute approach). Pendekatantersebut melakukan pengkajian peraturan perundang-undangan yangherhubungan dengan pokok permasalahan. Selain itu juga diguuakanpendekatan konsep (Conceptual approach). Pendekatan konsep ini digunakun dalam rangka untuk melihat konsep konsep yang terkait dengan kedudukan Badan Permusyawaratan Desa dalam PemerintahanDesa.

Bahan hukum primer, bahan hokum primer merupakan bahan hokum yang bersifat autoritatif artinya mempunyai otoritas bahan hokum teridiri dari perundang-undangan, catatan resmi atau risalah dalam pembuatan perundang-undangan dan putusan hakim. Adaun bahan hukum primer antara lain : undang-undang Nomor 23 Tahun 2014 tentang Pemerintah Daerah, Undang-Undang Nomor 6 Tahun 2014 tentang Desa. 
Bahan Skunder, yaitu bahan yang diperoleh dari buku teks, jurnal-jurnal, pendapat para sarjana dan kasus-kasus hokum.

Adapun bahan yang diperoleh dalam penelitian studi kepustakaan, aturan perundang-undangan, yang penulis uraikan dan dihubungkan sedemikian rupa, sehingga disajikan dalam penulisan yang lebih sistematis guna menjawab perumusan masalah yang dirumuskan. Cara pengelolaan data dilakukan secara deduktif yakni menarik kesimpulan dari suatu permasalahan yang bersifat umum terhadap permasalahan kongkrit yang dihadapi.

\section{HASIL PENELITIAN DAN PEMBAHASAN}

1. Kedudukan Badan Permusyawaratan Desa BPD sebagai lembaga baru di desa dan perwakilan dari masyarakat berfungsi sebagai penyalur aspirasi masyarakat yang mempunyai kedudukan sejajar dengan pemerintah desa dan menjadi mitra kerja dari pemerintah desa, mempunyai tugas dalam bidang legislasi atau perundang-undangan, menampung aspirasi masyarakat,dan tugas dalam bidang pengawasan.

Keberadaan BPD ini tidak terlepas dari proses pembentukan BPD dan sejumlah fungsi, kewenangan, dan hak-hak yang dimilikinya. Anggota BPD berasal dari komponen-komponen di masyarakat desa kini telah tampil menjadi salah satu pemimpin desa yang berpengaruh. Anggota anggota BPD terdiri dari para pemuka di masyarakat yang dipilih oleh warga desa telah menjadi pemimpin di organisasi yang ada di desa dan tidak dibenarkan apabila anggota BPD merangkap sebagai kepala desa atau perangkat desa.
Para pemuka masyarakat ini tidak lagi berada di luar sistem tetapi telah masuk menjadi bagian dan sekaligus tokoh dalam sistem tersebut.

$\begin{array}{lrr} & \text { Ketika BPD sebagai } \\ \text { lembaga demokratisasi } & \text { desa }\end{array}$ sekaligus wujud dari adanya otonomi di desa telah dilahirkan atas ketentuan UU No. 32 Tahun 2004, bukan berarti secara otomatis demokratisasi itu akan terwujud. Apabila anggota-anggota BPD tidak mampu memahami kedudukan dan fungsi yang dijalankan tersebut dalam keseluruhan pemerintahan desa, maka sangat mungkin pelaksanaan fungsi tersebut tidak dapat berjalan sebagaimana mestinya yang dikehendaki oleh Undaang-Undang tersebut.

Menurut penulis untuk mengembangkan pemerintahan desa dan untuk menjalankan fungsi BPD sebagaimana mesitinya, BPD dapat menggunakan hak nya berdasarkan Pasal 61 huruf (b) yaitu menyatakan pendapat atas penyelenggaraan Pemerintahan Desa, pelakasanaan Pembangunan Desa, pembinaan Kemasyarakatan Desa, dan Pemberdayaan masayarakat Desa. Hal ini dapat dilakukan dengan cara yang lebih terstruktur dengan cara menampung aspirasi masyarakat desa, membuat daftar aspirasi, membuat rencana anggaran yang akan dikeluarkan, dan kemudian mengajukan hal tersebut kepada Kepala Desa, yang berarti BPD tidaklah bersikap pasif dalam hal pembangunan desa. tidak saja menampung, namun juga menyalurkan aspirasi tersebut berdasarkan apa yang diatur dalam Pasal 55 ayat (2) UU No. 6 Tahun 2014 Tentang Desa. 
Makna dari menyalurkan aspirasi menurut Pasal 55 ayat (2) UU No. 6 Tahun 2014 Tentang Desa tidak dijelaskan lebih lanjut dalam penjelasan Undang-Undang No. 6 Tahun 2014. Menurut penulis sendiri, dalam menyalurkan aspirasi tersebut tentu saja apa yang disampaikan atau aspirasi yang ditampung haruslah disalurkan dengan cara yang jelas, akurat dan detail.

Namun, dalam kenyataannya hal tersebut sulit dilakukan di DesaDeket, hal ini dikarenakan Kesibukan anggota BPD diluar aktifitasnya sebagai anggota BPD. Selain sebagai anggota BPD banyak anggota BPD yang memiliki mata pencaharian lain diluar aktivitasnya sebagai anggota BPD diantaranya sebagai pedagang, buruh, dan swasta, petani, peternak, berkebun. Karena kesibukan inilah yang menyebabkan sedikitnya waktu untuk bertemu dan bertukar pikiran atau diskusi antar anggota BPD (lingkupnya dalam BPD tidak memiliki waktu yang cukup banyak), sehingga anggota-anggota BPD tidak terfokus kepada kedudukannya didalam BPD

2. Tata cara pengangkatan Badan Permusyawaratan Desa (BPD)

Anggota
permusyawaratan desa radan
wakil dari penduduk
bersangkutan yang ditetapkan
dengan cara musyawarahdan
mufakat. Pimpinan badan
permusyawaratan Desa dipilih dari
dan anggotar badan
permunsyawaratan desa, masa
jabatan badan permusyawaratan
desa adalah 6 (enam) tahun dan
dapat dipilih lagi untuk 1 (satu)
kali masa jabatan berikutnya.
Syarat dan tata cara penetapan
anggota badan permusyawaran

desa dan pimpinannya di atur dalam Perda yang berpedoman pada Peraturan Pemerintah.17 Penjelasan Pasal 209 dan 210 ayat 1 Undang-Undang ini menyatakan, yang di maksud dengan Badan permusyawaratan Desa dalam ketetntuan ini adalah sebutan nama. Adapun fungsi pengawasan Badan Permusyawaratan Desa(BPD), yaitu meliputi pengawasan terhadap pelaksanaan peraturan desa,pengawasan terhadap pelaksanaan Anggaran Pendapatan dan BelanjaDesa serta pengawasan terhadap pelaksanaan Keputusan Desa, yang sebelumnya di atur dalam Undang-Undang Nomor 22 Tahm 1999 tentangPemerintainan Daerah dan di jabarkan dalam Pera PemeMtahNomor 76 Tahun 2001 Jo Peraturan Menteri Dalam Negeri Nomor 64 Tahun 1999. Kemaudian setelah diundangkan UndangUndang Nomor 32Tahun 2004 tentang Pemerintahan Daerah, kedudukan dan fungsi Badan Permusyawaratan Desa (BPD) diatur dalam pasal 209 dan 210 Undang-Undang Nomor 32 Tahun 2004 sebagaimana yang telah diganti sebagianpasalnya rnelalui Undang-Undang Nomor 6 Tahun 2014 pasal 55 dan pasal 56. Dan selanjutnya ketentuan tersebut diatur dalam Undang-Undang nomor 23 Tahun 2014 tentang Pemaerintahan Daerah

\section{PENUTUP}

1. Kesimpulan.

Berdasarkan hasil penelitian dan pembahasan yang telah diuraikan maka dapat dibuat simpulan sebagai berikut :
a. Kedukan
Badan
Permusyawaratan Desa dalam pemerintahan desaadalah sebagai jembatan antara elemen 
masyarakat dan Pemerintah Desa, dan merupakan wahana untuk melaksanakan demokrasi pancasilan dan kedudukannya dalam pemerintahan desa adalah sejajar dan menjadi mitra dari Pemerintah Desa.

b. Tata cara pengangkatan Badan Permusyawaratan Desa di tentukan dengan jumlah anggota Badan Permusyawaratan Desa ditetapkan dengan jumlah gangsal (ganjil), paling sedikit 5 (lima) orang dan paling banyak 9 (Sembilan) orang, dengan memperhatikan wilayah, penduduk, dan kemampuan keuangan Desa. Kemudian pengesahan selambatlambatnya 7 (Tujuh) hari setelah kepala Desa menyampaikan berita acara hasil pemilihan kepada Bupati melalui Camat. Selanjutnya dilakukan pelantikan oleh Bupati atau pejabat yang ditunjuk.

\section{Saran.}

Adapun saran yang dapat penulis sampaikan sehubungan dengan permasalahan dalam skripsi ini adalah :

a. Agar dapat dilakukan sosaialisai kepada masyarakat desa tentang tugas dan tanggung jawab Badan Permusyawaratan Desa (BPD) Desa Deket Wetan, sehingga tanggung jawab mengenai pemerintah desa tidak bertumpu hanya pada Kepala Desa saja. Yang berart akan memudahkan dijalankan program-program Desa lain yang dapat membangun Desa Deket Wetan.

b. Pemilihan

Badan

Pennusyawaratan

Desa sebaiknya dibatasi oleh usia, dalam pemilihan Badan Permusyawaratan Desa sebaiknya diduduki olehpemuda desa agar dapat maembangun sikap kritis dan memberikan semangat kepada pemuda desa dan agar masyarakat desa dapatmenyampaikn aspirasinya lebih leluasa.

\section{E. DAFTAR PUSTAKA}

\section{LITERATUR:}

Abdul Kadir Muhammad. 2004. Hukum dan Penelitian Hukum. Citra Aditya Bakti. Bandung.

Aminuddin Ilmar. 2013. Hukum Tata Pemerintahan. Identitas Universitas Hasanuddin. Makassar.

A. Muin Fahmal, 2006. Peran Asas$\begin{array}{lr}\text { asas } & \text { Hukum } \\ \text { Pemerintahan } & \text { yang } \\ \text { Layak } & \text { dalam } \\ \text { Mewujudkan } & \\ \text { Pemerintahan } & \text { yang }\end{array}$ Bersih. Cet. I, Penerbit UII Press, Yogyakarta.

Dwipayana, Ari AAGN dan Eko. 2003. Membangun Good Governance di Desa. Institute For Research And Empowerment. IRE Press. Yogyakarta,

Jhony Ibrahim, 2006. Teori \& Penelitian Hukum Normtif. Banyumedia Publishing. Malang

Moh. Kusnardi., Harmaily Ibrahim. 1988. Hukum Tata Negara Indonesia Cetakan 7. Pusat Studi Hukum Tata Negara Fakultas Hukum Universitas Indonesia. Jakarta. 
M. Thalhah,2009.Teori Demokrasi Dalam Wacana Ketatanegaraan

Perspektif Pemikiran Hans Kelsen, Jurnal Hukum No.3 Vol. Yogyakarta: Universitas Islam Indonesia

Peter Mahmud Marzuki. 2005. Penelitian Hukum, Edisi Pertama, Kencana, Jakarta.

Ruslli Ramli, et.al,1994. Asas-Asas Managemen, Departemen Pendidikan dan
Kebudayaan, Universitas Terbuka, Jakarta

Wijaya., 2006. Otonomi Desa. Raja Grafindo Persada, Jakarta

\section{PERTURAN PERUNDAANG-} UNDANGAN

Undang-Undang Nomor 23 Tahun 2014 tentang Pemerintah Desa.

Undang-Undang Nomor 6 Tahun 2014 tentang Desa. 